\title{
CONSONANT CHANGES IN COGNATES \\ SHARED BY INDONESIAN AND PALEMBANG MALAY
}

Penggantian Konsonan dalam Kognat yang Dimiliki Bersama oleh Bahasa Indonesia dan

Bahasa Melayu Palembang

\section{Fauzi Syamsuar}

Universitas Ibn Khaldun Bogor, Indonesia

Jalan Sholeh Iskandar, Kedungbadak, Kota Bogor, Jawa Barat, Indonesia

fauzisyamsuar@gmail.com

Naskah Diterima Tanggal 17 Mei 2021—Direvisi Akhir Tanggal 29 September 2021—Disetujui Tanggal 17 Desember 2021 doi: https://doi.org/10.26499/rnh/v10i2.4164

\begin{abstract}
Abstrak
Artikel ini membahas gejala penggantian bunyi, yakni penggantian bunyi-segmental konsonan tunggal, yang didapati dalam kognat atau kata seasal yang dimiliki bersama oleh bahasa Indonesia dan bahasa Melayu Palembang. Sebuah daftar yang memuat 2.535 kognat dalam bahasa Indonesia dan bahasa Melayu Palembang menjadi korpus. Karena merupakan bahasa modern yang terderivasi dari bahasa Melayu Baku, bahasa Indonesia menjadi bahasa acuan dalam pembahasan. Penguatan konsonan, fortisi, pelemahan konsonan, lenisi, dan glotalisasi menjadi gejala yang didapati dalam penggantian konsonan. Struktur suku kata yang di dalamnya konsonan tersebut di atas terdistribusi juga dibahas. Didapati perbedaan produktivitas gejala penggantian konsonan tertentu dibandingkan dengan gejala yang lain. Produktivitas itu menunjukkan bahwa jika dibandingkan dengan bahasa Indonesia, kehadiran konsonan lemah atau konsonan lenis lebih produktif dalam bahasa Melayu Palembang.

Kata-kata kunci: kognat, penggantian konsonan, penguatan konsonan (fortisi), pelemahan konsonan (lenisi), dan glotalisasi
\end{abstract}

\begin{abstract}
This article describes the phenomena of sound changes, i.e., changes of single segmental sound of consonants, found in cognates shared by Indonesian and Palembang Malay. A list containing 2,535 cognates shared by Indonesian and Palembang Malay becomes the corpus. Since Indonesian is a modern language derived from Standard Malay, it becomes the reference language in the efforts of descriptions. Consonant strengthening, fortition, consonant weakening, lenition, and glottalization become the phenomena found in the consonant changes. Various syllabic structures in which the consonants distributed are also described. The differences of productivity of certain consonant-changes compared to others are found. The productivity shows that, compared to Indonesian, the occurrences of weaker consonants lenis consonants are more productive in Palembang Malay. key words: cognates, consonant change, consonant strengthening (fortition), consonant weakening (lenition), and glotallization
\end{abstract}

How to Cite: Syamsuar, Fauzi. (2021). Consonant Changes in Cognates Shared by Indonesian and Palembang Malay. Ranah: Jurnal Kajian Bahasa. 10(2). 384 -397. doi: https: https://doi.org/10.26499/rnh/v10i2.4164

\section{INTRODUCTION}

Indonesian is the national language of the Republic of Indonesia. It is derived from Johor-Riau Malay, i.e., a standard dialect of Malay. Besides Johor-Riau Malay, there are plentiful of Malay dialects in Indonesia. Citing Ethnologue: Language of the World, SIL International, Indonesia Branch (2006), pointed out that there are at least thirty-eight dialects of Malay in Indonesia.

In Sumatra, there are at least twenty-four Malay dialects. One of them is Palembang Malay i.e., a language-code spoken by the society of the town of Palembang (the capital city of 
South Sumatra Province) and its surroundings. Efforts of codifying the dialect have been done. Balai Bahasa Sumatra Selatan (Regional Agency for Language in South Sumatra Province) successfully published Kamus Palembang - Indonesia (Palembang Malay - Indonesian bilingual dictionary in 2007; and its third revised-edition was published in 2019.

Besides describing how the entries are lexico-grammatically used, the dictionary also describes their phonological forms. However, referring to the phonological rules of Indonesian and Malay explained by Hasan (2013) and by Fauzi (2015), some revisions need to be done to the phonological forms of some entries. Revising some phonological forms of the entries listed in the dictionary based on the phonological rules explained in those two above-mentioned references, Fauzi (2021) managed to make a list of cognates shared by Indonesian and Palembang Malay. The list contains 1,100 identical cognates and 1,435 cognates with sound changes. This article describes the sound changes; and the list above-mentioned becomes the corpus of cognates.

Descriptions of sound changes in cognates usually involve the changes of segmental sounds, i.e., consonants, vowels, and diphthongs. The descriptions of the segmental-sound changes normally comprise the phenomena discussed in morphophonemics. The morphophonemic phenomena at least involve assimilation, dissimilation, sound fusion, sound deletion, sound fission, sound insertion, sound lenition, sound fortition, sound reduction, monophthongisation, diphthongisation, metathesis, and reduplication.

Dealing with the pronunciation of Standard Indonesian, Ayu and Indrya (2016) reported some of the morphophonemic phenomena above mentioned. They reported how certain sounds and/or sound-clusters in Standard Indonesian are pronounced differently by university students compared to how the utterance are supposed to be formally pronounced. The pronunciation difference or the sound changes are reported are reported to be caused by the interference of Non-standard Indonesian, i.e., a language code the students are accustomed to use in their daily communication.

Regardless with the cause, the descriptions in this article are focusing on the distributions of the patterns of the sound changes. Instead of involving other segmental sounds, i.e., vowels and diphthongs, the descriptions are only involving the changes of consonants. To be more specific, this article only describes the patterns of the changes of single-consonant sounds.

\section{THEORETICAL BASIS}

Cognate is a language or a linguistic form which is historically derived from the same source as another language/form (Crystal, 2008, p. 83). He further explained that because Spanish, Italian, French, and Portuguese are historically derived from the same source (Latin), they are considered as cognate-languages. Spanish padre, Italian padre, French père, and Portuguese padre, each of which means 'father', are or cognates shared by the languages.

From cognates we can observe sound correspondences and from them we can deduce sound changes (check Fromkin, Rodman, and Hyams, 2014, p. 364). Dealing with sound changes in cognates shared by Latin and English as members of Indo-European languages, Fromkin, Rodman, and Hyams exemplified that /p/ in Latin /pI.tır/ and /f/ in English /fa:.ðər/ show sound correspondence; and from the correspondence we can deduce the change of $/ \mathrm{p} / \rightarrow / \mathrm{f} /$. Sound changes involving consonants does not solely comprise the changes of single consonant as exemplified above. Besides, the are at least phenomena of (1) consonant additions which comprise epenthesis and epithesis and (2) consonant fusion versus consonant-cluster reduction.

Crystal (2008) explained that epenthesis refers to a type of sound addition that is inserted into a word. Harimurti (2008) underlines that epenthesis is the insertion of sounds in the realization of copy words (borrowings). Dealing with the copy words, when copied into Indonesian English adjective psycholinguistic /saI.kəv.lIn.gwIs.tIk/ is realized as /psI.ko.lIn.gwIs.tIs/; 
check Fauzi (2018), p. 238. Consonant /p/ is added and occurs as the initial sound of the word. Therefore, the consonant added is an epenthetic consonant in the copying.

Epithesis refers to the addition of a sound or several sounds in the final position of a word. Trask (1996) pointed out excrescent, i.e., a term becoming a type of epithesis, and defined it as "the addition of plosive consonant at the end of the word" (p. 135). He exemplified that the phenomenon of English word vermin realized as vermint as excrescent. Furthermore, Fauzi (2012) reported that $/ 2 /$ is added by Sundanese speakers in the realization of /re.plek.sI $/$, i.e., a copy word derived from Indonesian refleksi 'reflection'/re.plek.sI/. Thus, the addition of the consonant is an example of excrescent.

When copied into Indonesian, English neurotransmitter /njuə.rəv. trænz.mI.tə./ is realized as /nv.ro.trss.mI.tor/; check Fauzi (2018), p. 243. In the copying, nasal-palatal-lenis /n/ is resulted from the coalition of nasal-alveolar-lenis / $\mathrm{n} /$ and approximant $/ \mathrm{j} /$. Therefore, it can be considered as a phenomenon of consonant fusion as Trask (1996) explained that fusion is a process of two segments occurring in a single linguistic form are joined into a segment.

Consonant fusion should be differentiated from consonant-cluster reduction, i.e., a phenomenon which was explained by Fauzi (2018) as the reduction of the number of consonants occurring as the onset (consonant occurring in the initial position of a syllable) or coda (consonant occurring in the final position of syllable); further explanation of syllabic structure will be discussed in the following section. Fauzi exemplified that, when copied into Indonesian, monosyllabic English noun charge /t fa:Idz/ (with CCVCCC syllabic structure) is realized as /Cıs/ (with CVC syllabic structure). The consonant cluster becoming the onset in the origin word is reduced: double onset $\rightarrow$ single consonant as onset. Besides, three-consonant cluster becoming the coda in the origin word is also reduced: triple coda $\rightarrow$ single consonant as coda.

However, the description of sound changes in this article is limited to the changes of single segmental sound of consonants. In other words, the phenomena of epenthesis, epithesis, consonant fusion, and consonant-cluster reduction that might occurred in the cognates being involved in the descriptions are ignored. Instead, the descriptions will focus on the phenomena of fortition (which is similar to consonant strengthening) and lenition (which is similar to consonant weakening), the definition of which will be explained in the following section.

\section{RESEARCH METHOD}

Since the efforts of deducing sound changes in this article focus on single segmentalsound consonants, the distribution of consonants in Indonesian and/or Malay is needed. The table below shows the distribution of consonants in Indonesian and/or Malay according to Hasan's (2013).

\begin{tabular}{|c|c|c|c|c|c|c|c|c|c|}
\hline \multirow{2}{*}{$\begin{array}{l}\text { manners of } \\
\text { articulation }\end{array}$} & \multicolumn{9}{|c|}{ places of articulation } \\
\hline & bilabial & labiodental & dental & alveolar & $\begin{array}{c}\text { post- } \\
\text { alveolar }\end{array}$ & palatal & velar & uvular & glottal \\
\hline \multirow{2}{*}{ plosive } & $\mathrm{p}$ & & & $\mathrm{t}$ & & $\mathrm{C}$ & $\mathrm{k}$ & & $?$ \\
\hline & $\mathrm{b}$ & & & d & & $\mathrm{J}$ & $\mathrm{g}$ & $q$ & \\
\hline nasal & $\mathrm{m}$ & & & $\mathrm{n}$ & & $\mathrm{n}$ & $\eta$ & & \\
\hline thrill & & & & & $\mathrm{r}$ & & & $\mathrm{X}$ & \\
\hline \multirow{2}{*}{ fricative } & & $\mathrm{f}$ & $\theta$ & $\mathrm{s}$ & $\int$ & & & $\mathrm{X}$ & $\mathrm{h}$ \\
\hline & & $\mathrm{v}$ & ð & $\mathrm{z}$ & & & & & \\
\hline lateral & & & & 1 & & & & & \\
\hline approximant & w & & & & & $\mathrm{j}$ & & & \\
\hline
\end{tabular}


Each consonant listed on the upper side of each column above is classified into fortis consonant or the one referring to sound made with a relatively strong degree of muscular effort and breath force. Meanwhile, each consonant listed on the bottom of each column above is classified into lenis consonant or the one referring to sound made with a relatively weak degree of muscular effort and breath force (check Crystal, 2008). Regarding the dichotomy of fortis consonants versus lenis consonants, changes deduced from consonant correspondences in cognates are classified into the descriptions of consonant fortition versus consonant lenition.

Referring to a universal scale of values on which segmental units are arrayed, consonants can be in a continuum: from strong to weak (check Crystal 2018, p.454). Crystal further explained that velars are assigned weaker than dentals, which are in turn, weaker than bilabials. In addition, Matthews (1997) pointed out that, based on the scale or hierarchy in which units are distinguished as stronger or weaker, plosives may be considered stronger than fricatives. Therefore, in turn, fricatives may be stronger than laterals and approximants. Based on the scales or hierarchy of consonant values discussed above, changes deduced from consonant correspondences in cognates are also classified into the descriptions of consonant strengthening versus consonant weakening.

Based on syllabic-structures of word, a single consonant can occur either as onset or coda of a syllable. The syllable can be either initial, final, penultimate (the one occurring before final syllable), antepenultimate (the one occurring before penultimate), or pre-antepenultimate (the one occurring before antepenultimate). Onset is a consonant occurring as the initial sound of a syllable, while coda is a consonant occurring as the final sound of syllable. A syllable containing coda is labelled as closed syllable, while a syllable that does not contain coda (only consists of onset and a vowel/diphthong as nucleus) is labelled as open syllable. The syllabic structures become the framework in the effort of deducing consonants changes.

\section{DISCUSSION}

The following tables describe consonant changes found in cognates shared by Indonesian and Palembang Malay. The first columns identify the numbers of sound-change phenomena; the second describe the phonological forms of the cognates in Indonesian; the third describe the phonological forms of cognates in Palembang Malay, while the last provide the glossary. The arrangement means that the phonological forms of cognates in Palembang Malay are compared to the ones in Indonesian as the reference language. The fact that Indonesian is a modern language derived from a standard dialect of Malay becomes the reason why it becomes the reference language.

\section{Consonant Strengthening}

Certain consonants in Indonesian are strengthened in Palembang Malay.

as onset in the initial open syllable

\begin{tabular}{|c|c|c|c|}
\hline (1) & $/ t_{\Lambda} . r I n /$ & /p p.jIn $/ ~$ & canine tooth \\
\hline $\begin{array}{l}\text { (2) } \\
\text { (3) }\end{array}$ & $\begin{array}{l}\text { /Cə.g } \mathrm{g} \wedge \mathrm{h} / \\
/ \mathrm{d} ə \cdot \mathrm{k} \Lambda \mathrm{p} /\end{array}$ & $\begin{array}{l}\text { /tə.ga/ } \\
\text { /bə.kəp/ }\end{array}$ & $\begin{array}{l}\text { prevent } \\
\text { embrace }\end{array}$ \\
\hline
\end{tabular}

\begin{tabular}{|c|c|c|c|}
\hline \multicolumn{4}{|c|}{ as coda in the final syllable } \\
\hline (1) & /CD.l $\mathrm{k} \mathbf{k} /$ & /Co.let/ & poke \\
\hline (4) & /gn.rvk/ & 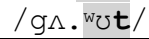 & scratch \\
\hline
\end{tabular}

Plosives in Indonesian change into stronger plosives in Palembang Malay: alveolar $\rightarrow$ bilabial in (1) and (3); palatal $\rightarrow$ alveolar in (2); and velar $\rightarrow$ alveolar in (4).

\begin{tabular}{ll}
\hline \multicolumn{3}{c}{ as onset in the initial open syllable } \\
(5) /m॰.lIn.Jo/ / / bə.1In.Jo/ & $\begin{array}{l}\text { Gnetum } \\
\text { gnemon }\end{array}$ \\
\hline
\end{tabular}

\begin{tabular}{c}
\hline /m/ as onset in the initial open syllable \\
$\leftrightarrow / \mathrm{g} /$ as onset in the initial closed syllable \\
\hline (6) /mI.rIn./ /gIn.CIn/ incline
\end{tabular}


Nasals in Indonesian change into stronger segments, plosives, in Palembang Malay: bilabial $\rightarrow$ bilabial in (5); and bilabial $\rightarrow$ palatal in (6).

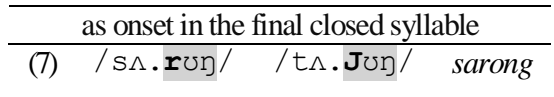

A thrill in Indonesian changes into a stronger segment, a plosive, in Palembang Malay: post-alveolar $\rightarrow$ palatal in (7).

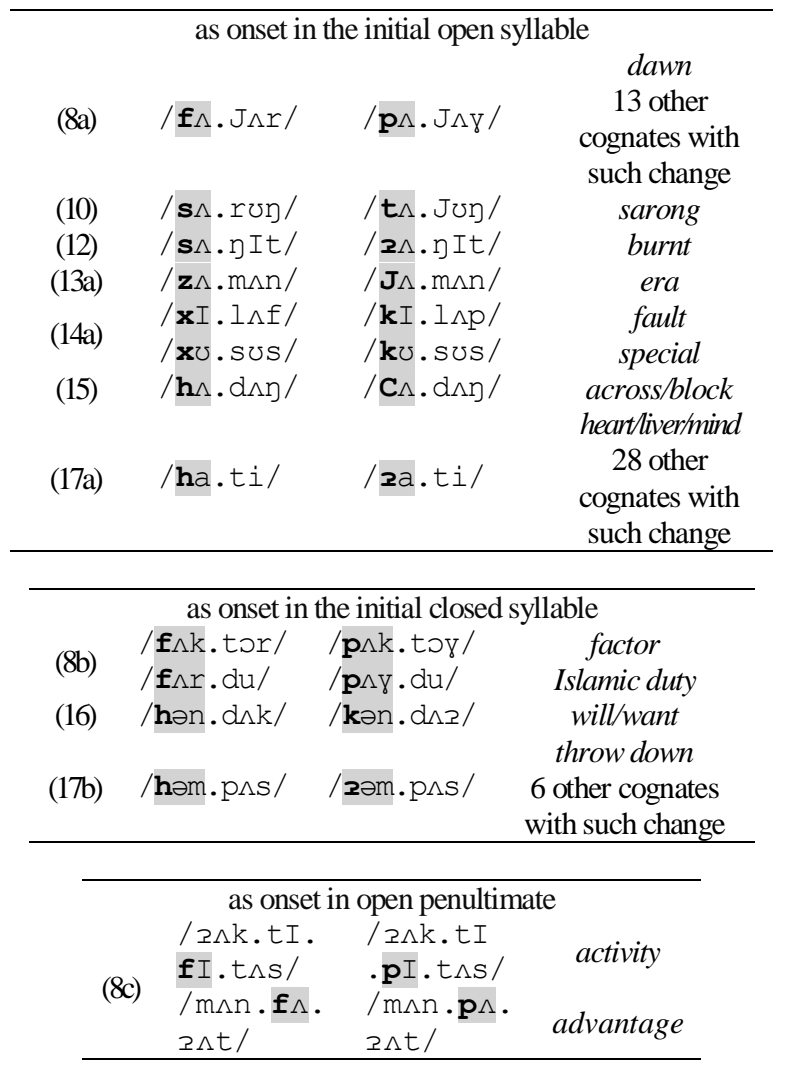

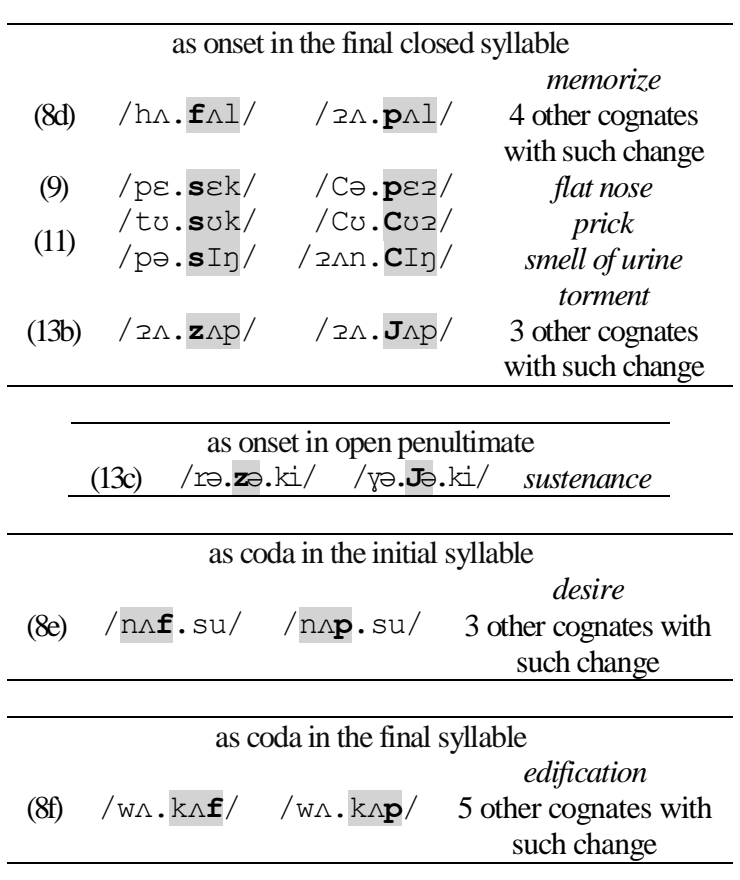

Fricatives in Indonesian change into stronger segments, plosives, in Palembang Malay: labiodental $\rightarrow$ bilabial in (8a-f); alveolar $\rightarrow$ bilabial in (9); alveolar $\rightarrow$ alveolar in (10); alveolar $\rightarrow$ palatal in (11) and (13a-b); alveolar $\rightarrow$ glottal in (12); uvular $\rightarrow$ velar in (14a-b); glottal $\rightarrow$ palatal in (15); glottal $\rightarrow$ velar in (16); and glottal $\rightarrow$ glottal in (17a-b).

\begin{tabular}{|c|c|c|c|}
\hline \multicolumn{4}{|c|}{ as onset in the initial open syllable } \\
\hline (18a) & /wv.dv?/ & $/ \mathbf{2} v \cdot d v ? /$ & ablution \\
\hline (18b) & /wo.Jut/ & / 2u. Jut/ & exist \\
\hline \multicolumn{4}{|c|}{ as onset in the initial closed syllable } \\
\hline (19a) & /wIg. ko/ & /bIn. ko/ & $\begin{array}{c}\text { glutinous rice } \\
\text { with coconut } \\
\text { milk }\end{array}$ \\
\hline
\end{tabular}

\begin{tabular}{c}
\hline as onset in the final closed syllable \\
\hline (19b) $/ \mathrm{s} \wedge \mathrm{w} \wedge \mathrm{n} / \mathrm{s} \wedge \mathrm{b} \wedge \mathrm{n} /$ cloud \\
\hline
\end{tabular}

Approximants in Indonesian change into stronger segments, plosives, in Palembang Malay: bilabial $\rightarrow$ glottal in (18a-b); and bilabial $\rightarrow$ bilabial in (19a-b). 


\begin{tabular}{l} 
as onset in the final closed syllable \\
\hline (20) $/ 2 I . \mathrm{y} \wedge \mathrm{t} / / \mathrm{II} . \mathrm{m} \wedge \mathrm{t} /$ remember
\end{tabular}

A nasal in Indonesian changes into a stronger nasal in Palembang Malay: velar $\rightarrow$ bilabial in $(20)$.

\begin{tabular}{ll}
\hline \multicolumn{3}{c}{ as onset in the initial open syllable } \\
\hline (21a) / S $v$.kvr/ / s. kvr/ thank God \\
\hline
\end{tabular}

\begin{tabular}{|c|c|c|c|}
\hline \multicolumn{4}{|c|}{ as onset in open antepenultimate } \\
\hline (21b) & $\begin{array}{l}/ m \wedge \cdot \int \Lambda \\
r \wedge \cdot k \wedge t /\end{array}$ & $\begin{array}{l}/ \mathrm{m} \Lambda \cdot \mathbf{s} \wedge . \\
\mathrm{\gamma} \wedge \cdot \mathrm{k} \wedge \mathrm{t} /\end{array}$ & society \\
\hline
\end{tabular}

Fricatives in Indonesian change into stronger fricatives in Palembang Malay: postalveolar $\rightarrow$ alveolar in (21a-b).

\begin{tabular}{|c|c|c|c|}
\hline \multicolumn{4}{|c|}{ as onset in antepenultimate } \\
\hline (22) & $\begin{array}{l}/ J \ni . l \Lambda . \\
l \Lambda . t \wedge n /\end{array}$ & $\begin{array}{l}/ \mathrm{J} ə \cdot \mathrm{\gamma} \wedge . \\
l \Lambda \cdot t \wedge \mathrm{n} /\end{array}$ & look aro \\
\hline
\end{tabular}

A lateral in Indonesian changes into a stronger segment, a thrill, in Palembang Malay: alveolar $\rightarrow$ uvular in (22).

Distribution of Consonant-Strengthening

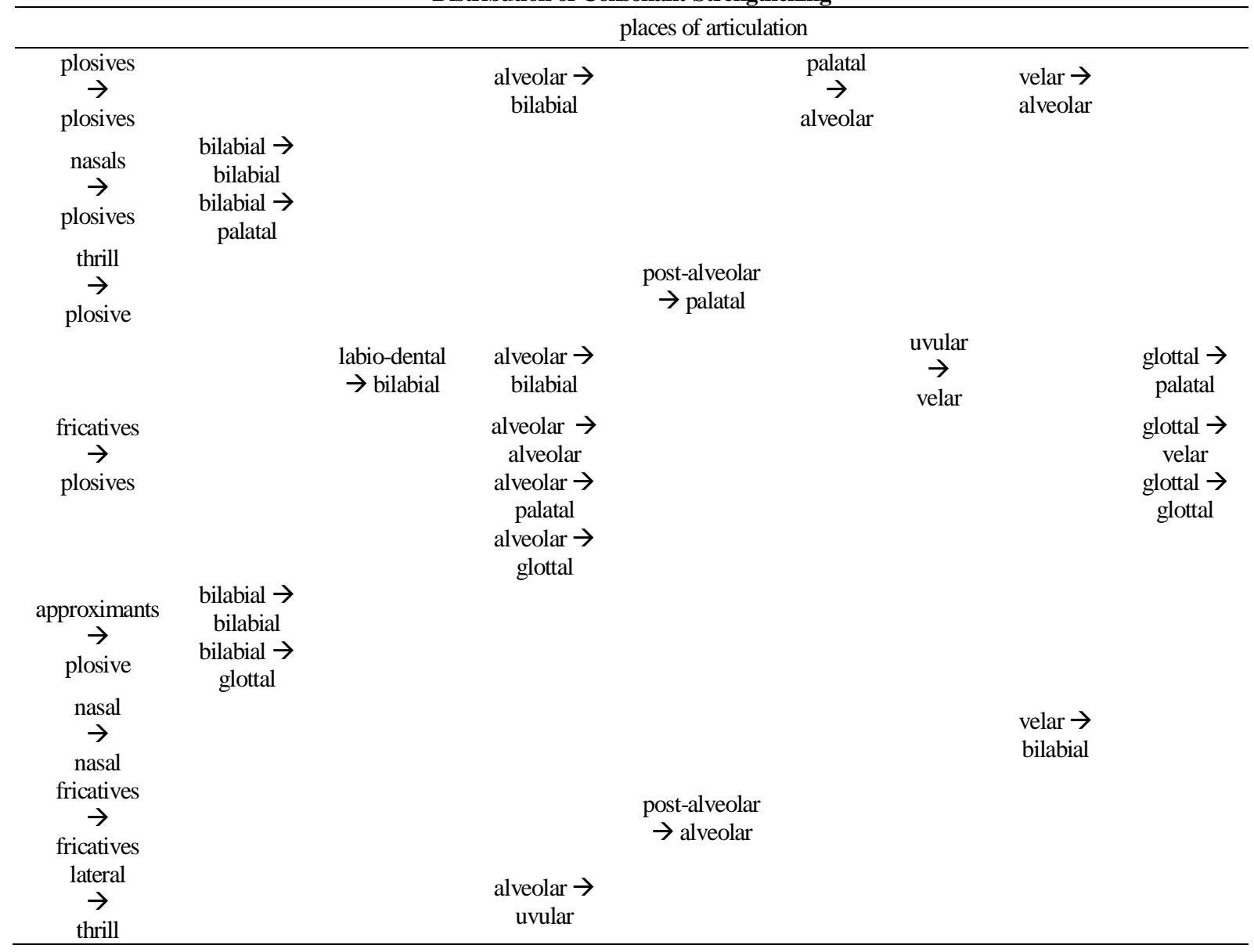

Consonant strengthening mostly involves non-plosives (nasals, fricatives, and approximants) $\rightarrow$ plosives; and fricatives $\rightarrow$ plosives is the dominant one. It is in line with the findings of survey by Bybee and Easterday (2019, p. 278) on consonant strengthening that reported approximant $\rightarrow$ plosive and fricative $\rightarrow$ plosive frequently happened as consonant strengthening. However, any nasal $\rightarrow$ plosive was not reported in their report. 
All fricatives found in the corpus of cognates are found to be involved in the consonant strengthening; $/ \mathrm{f} / \mathrm{h} / \mathrm{s} / \mathrm{h} / \mathrm{z} / \mathrm{h} / \mathrm{x} /$, and $/ \mathrm{h} /$ are strengthened into plosives; while $/ \mathrm{s} /$ is strengthened into stronger fricative $/ \mathrm{s} /$. Of four nasals found in the corpus of cognates $(/ \mathrm{m} /$, $/ \mathrm{n} /, / \mathrm{n} /$, and $/ \mathrm{g} /$ ), only $/ \mathrm{m} /$ and $/ \mathrm{g} /$ are involved in consonant strengthening. The only lateral found in the corpus of cognates, $/ 1 /$, is also involved in consonant strengthening. Of two approximants found in the corpus of cognates $(/ \mathrm{w} /$ and $/ \mathrm{j} /)$, only $/ \mathrm{w} /$ was found to be involved in consonant strengthening.

The strengthening mostly involves consonants occurring as onset, either in the initial syllables, the final syllables, penultimates, or antepenultimates. However, no consonant strengthening found in pre-antepenultimate(s). In (14b), the consonant occurs as the first consonant of double onset. The strengthening mostly occurs in open syllables; only in (7), (8b $\& d),(9),(11),(13 b),(14 b),(16),(17 b),(19 a-b)$, and (20) they occur in closed syllables. Only few, i.e., in (4) \& (8e-f), the strengthening involves consonants occurring as coda.

\section{Fortition}

Fortition belongs to the phenomenon of consonant strengthening as Bybee and Easterday (2019, p. 267) highlighted that fortition is the strengthening of a consonant. Different from the previous section which ignores whether the consonants strengthened are either fortis or lenis, this section describes the phenomena of certain lenis consonants in Indonesian change into fortis consonants in Palembang Malay; such phenomenon is popularly known as fortition.

\begin{tabular}{|c|c|c|c|}
\hline \multicolumn{4}{|c|}{ as onset in the initial open syllable } \\
\hline (23a) & /bu.Juk/ & /pu.Juk/ & flatter \\
\hline (24) & $/ \mathrm{b} \wedge \cdot \mathrm{p} \wedge \mathrm{P} /$ & $/ 2 \wedge . b \wedge 2 /$ & father \\
\hline (25) & $/ \mathrm{d} \ni . \mathrm{k} \wedge \mathrm{p} /$ & /kə.kəp/ & embrace \\
\hline \multicolumn{4}{|c|}{ as onset in the initial closed syllable } \\
\hline (26a) & /Jən.dl.la/ & /Cə.nə.10/ & window \\
\hline (27) & /gon. $\mathrm{C} \wedge \mathrm{l} /$ & $/ \mathbf{k} \circlearrowleft n \cdot C \wedge \eta /$ & shake \\
\hline (28a) & /gøn.Jot/ & /zən.Jot/ & see-saw \\
\hline
\end{tabular}

\begin{tabular}{|c|c|c|c|}
\hline \multicolumn{4}{|c|}{ as onset in the penultimate syllable } \\
\hline (28b) & $\begin{array}{l}\text { /be.gi.ni/ } \\
\text { /be.gi.tu/ }\end{array}$ & $\begin{array}{l}\text { /Ca.zi.ni/ } \\
\text { /Ca.si.tu/ }\end{array}$ & $\begin{array}{l}\text { thisway } \\
\text { that way }\end{array}$ \\
\hline \multicolumn{4}{|c|}{ as onset in the final closed syllable } \\
\hline $\begin{array}{l}(23 b) \\
(26 b)\end{array}$ & $\begin{array}{l}\text { /gə.buk/ } \\
\text { /pI.JIt/ }\end{array}$ & $\begin{array}{l}\text { /gə.pus/ } \\
\text { /pI.CIt/ }\end{array}$ & $\begin{array}{l}\text { beat/hit } \\
\text { massage }\end{array}$ \\
\hline
\end{tabular}

Lenis plosives in Indonesian change into fortis plosives in Palembang Malay: bilabial $\rightarrow$ bilabial in (23a-b); bilabial $\rightarrow$ glottal in (24); alveolar $\rightarrow$ velar in (25); palatal $\rightarrow$ palatal in (26a-b); velar $\rightarrow$ velar in (27); and velar $\rightarrow$ glottal in (28-b).

\begin{tabular}{|c|c|c|c|}
\hline \multicolumn{4}{|c|}{ as onset in the initial closed syllable } \\
\hline (29a) & $\mathrm{m} \wedge \mathrm{m} \cdot \mathrm{pIr} /$ & $/ \mathbf{z} \wedge \mathrm{m} \cdot \mathrm{pI \gamma} /$ & stop by \\
\hline (30) & $\mathbf{n} \wedge n \cdot t i /$ & $/ t \wedge n \cdot t i /$ & $\begin{array}{c}\text { later } \\
\text { wait }\end{array}$ \\
\hline \multicolumn{4}{|c|}{$\begin{array}{l}/ \mathrm{m} / \text { as coda in antepenultimate } \\
\leftrightarrow / \mathrm{s} / \text { as coda in the initial syllable }\end{array}$} \\
\hline$(29 b)$ & $\begin{array}{l}/ \mathrm{m} \wedge \cdot \mathrm{C} \wedge \mathrm{m} . \\
\mathrm{ma} \cdot \mathrm{na} /\end{array}$ & /C^2.ma.no/ & how \\
\hline
\end{tabular}

\begin{tabular}{|c|c|c|c|}
\hline \multicolumn{4}{|c|}{ as coda in the final syllable } \\
\hline (31) & $/ \mathrm{b} \curvearrowright \cdot l \wedge . \mathrm{C} \wedge \mathrm{n} /$ & /Ca.lus/ & shrimp paste \\
\hline (32) & /CA $. \mathrm{kUg} /$ & $/ \mathrm{C} \Lambda \eta . \mathrm{k} v \mathbf{2} /$ & squat \\
\hline
\end{tabular}

Nasals (lenis segments) in Indonesian change into fortis plosives in Palembang Malay: bilabial $\rightarrow$ glottal in (29a-b); alveolar $\rightarrow$ alveolar in (30); alveolar $\rightarrow$ glottal in (31); and velar $\rightarrow$ glottal in (32).

\begin{tabular}{|c|c|c|c|}
\hline \multicolumn{4}{|c|}{ as coda in the final syllable } \\
\hline (33) & $\begin{array}{c}\text { / kun.CIr/ } \\
\text { / kI.kIr/ }\end{array}$ & $\begin{array}{l}\text { / kun.CIt/ } \\
\text { / kI.kIt/ }\end{array}$ & $\begin{array}{c}\text { pigtails } \\
\text { stingy }\end{array}$ \\
\hline (35) & $\begin{array}{l}/ \mathrm{b} \partial \cdot s \wedge \boldsymbol{r} / \\
/ \mathrm{tI} \cdot \operatorname{dv} \boldsymbol{r} /\end{array}$ & $\begin{array}{l}\text { /bə.s } \mathrm{s} \mathbf{2} / \\
/ \mathrm{tI} \cdot \mathrm{d} \mathbf{2} /\end{array}$ & $\begin{array}{l}\text { big } \\
\text { sleep }\end{array}$ \\
\hline
\end{tabular}

\begin{tabular}{c}
\hline as onset in the final closed syllable \\
\hline (34) /mI.rIn/ / $/$ In.CIn/ incline \\
\hline
\end{tabular}


Thrills (lenis segments) in Indonesian change into fortis plosives in Palembang Malay: post-alveolar $\rightarrow$ alveolar in (33); post-alveolar $\rightarrow$ palatal in (34); and post-alveolar $\rightarrow$ glottal in (35).

\begin{tabular}{ccc}
\hline \multicolumn{4}{c}{ as coda in the final syllable } \\
\hline (36) $/ \mathrm{k} \cdot \mathrm{CIl} /$ & $/ \mathrm{k} \ominus \cdot \mathrm{CI} \mathbf{\imath} /$ & small/ittle \\
$/ \mathrm{.} \Lambda . \mathrm{S} \Lambda \mathrm{l} /$ & $/ \mathrm{\imath} \Lambda . \mathrm{S} \Lambda \mathbf{3} /$ & if \\
\hline
\end{tabular}

Laterals (lenis segments) in Indonesian change into fortis plosives in Palembang Malay: alveolar $\rightarrow$ glottal in (36).

\section{Distribution of Fortition}

\begin{tabular}{|c|c|c|c|c|c|}
\hline & & & aces of articulation & & \\
\hline$\stackrel{\text { plosives }}{\rightarrow}$ & $\begin{array}{l}\text { bilabial } \rightarrow \text { bilabial } \\
\text { bilabial } \rightarrow \text { glottal }\end{array}$ & alveolar $\rightarrow$ velar & & palatal $\rightarrow$ palatal & $\begin{array}{l}\text { velar } \rightarrow \text { velar } \\
\text { velar } \rightarrow \text { glottal }\end{array}$ \\
\hline $\begin{array}{c}\stackrel{\text { nasals }}{\rightarrow} \\
\text { plosives }\end{array}$ & bilabial $\rightarrow$ glottal & $\begin{array}{c}\text { alveolar } \rightarrow \\
\text { alveolar } \\
\text { alveolar } \rightarrow \text { glottal }\end{array}$ & & & velar $\rightarrow$ glottal \\
\hline $\begin{array}{c}\stackrel{\text { thrills }}{\rightarrow} \\
\text { plosives } \\
\text { lateral } \rightarrow \text { plosive }\end{array}$ & & alveolar $\rightarrow$ glottal & $\begin{array}{c}\text { post-alveolar } \rightarrow \\
\text { alveolar } \\
\text { post-alveolar } \rightarrow \\
\text { palatal } \\
\text { post-alveolar } \rightarrow \\
\text { glottal }\end{array}$ & & \\
\hline
\end{tabular}

All consonants involved in the fortition are strengthened into plosive: plosives $\rightarrow$ plosives, nasals $\rightarrow$ plosives, thrills $\rightarrow$ plosives, and laterals $\rightarrow$ plosives. All lenis plosives found in the corpus of cognates, $/ \mathrm{b} / \mathrm{,} / \mathrm{d} / \mathrm{,} / \mathrm{J} /$, and $/ \mathrm{g} /$ are involved in the fortition. Of four nasals found in corpus of cognates, only $/ \mathrm{n} /$ is not involved in the fortition. No fricatives are involved in the fortition. The fortition of approximants (which are, indeed, lenis segments) has been described in the previous section as the phenomenon of consonant strengthening.

The fortition involves consonants occurring as onset and/or coda in the initial syllables and the final syllables. Only consonant occurring as onset found in a penultimate: in (28b). However, no fortition was found in antepenultimate or pre-antepenultimate. The initial syllables and the final syllables are either open or closed, while the penultimate is open. No consonants are found to be part of double/triple onset and/or double/code found in the fortition were found.

\section{Consonant Weakening}

Certain consonants in Indonesian are weakened in Palembang Malay. As in the section of consonant strengthening, the dichotomy of fortis versus lenis is ignored in this section.

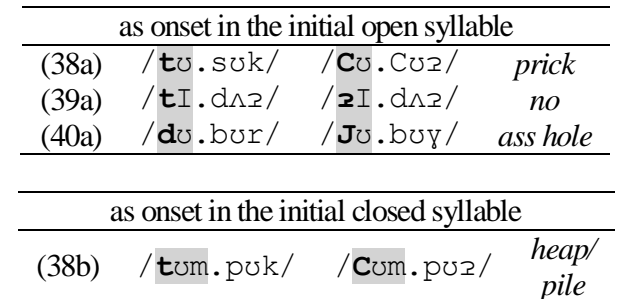




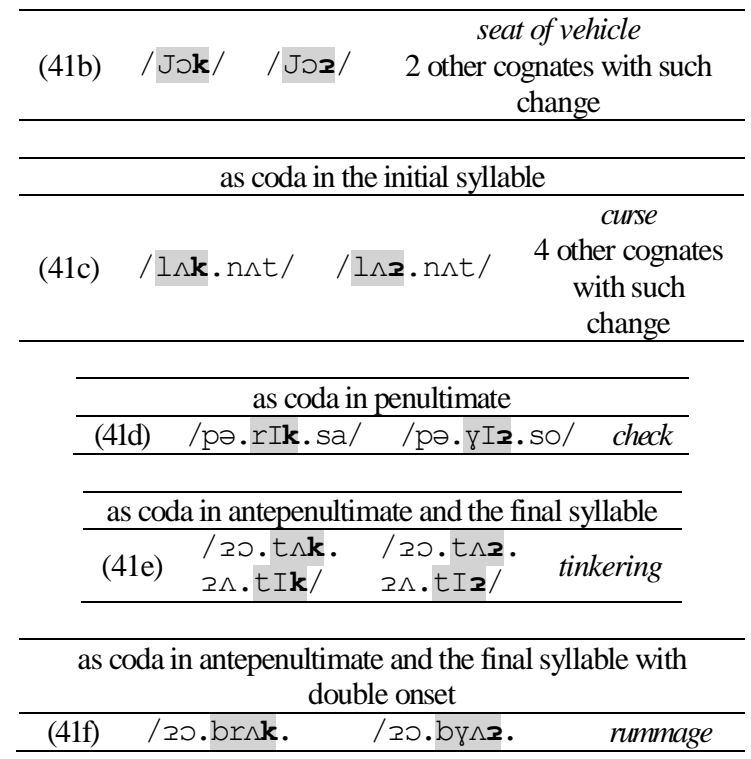

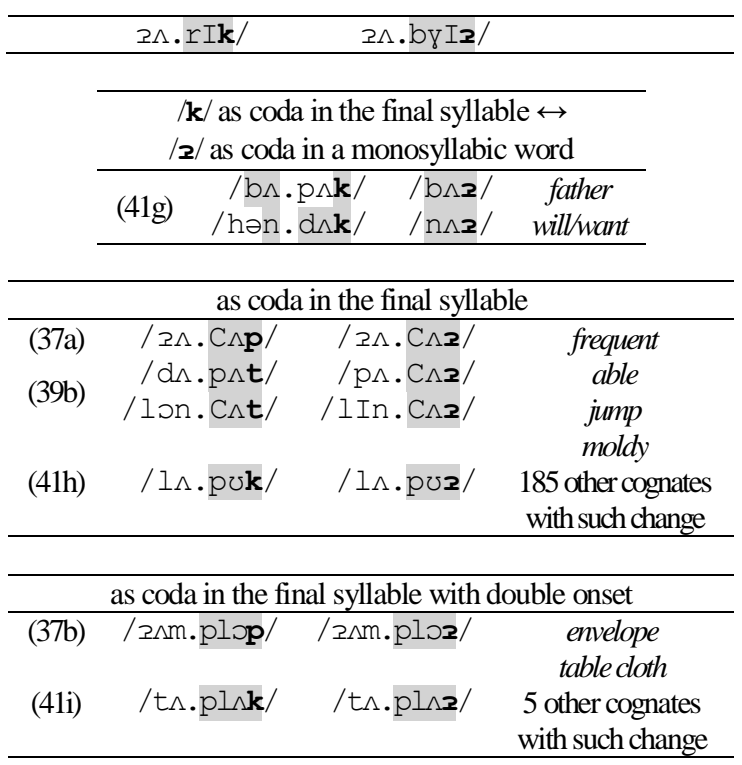

Plosives in Indonesian change into weaker plosives in Palembang Malay: bilabial $\rightarrow$ glottal in (37a-b); alveolar $\rightarrow$ palatal in (38-b) and (40a-b); alveolar $\rightarrow$ glottal in (39a-b); and velar $\rightarrow$ glottal in (41a-i).

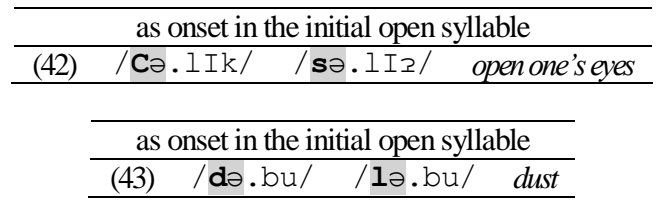

\begin{tabular}{l}
\hline as onset in the initial closed syllable \\
\hline (44) /gəm.bon/ / ləm.bun/ swollen
\end{tabular}

Plosives in Indonesian change into weaker segments, laterals, in Palembang Malay: alveolar $\rightarrow$ alveolar in (43); and velar $\rightarrow$ alveolar in (44).

\begin{tabular}{|c|c|c|c|}
\hline \multicolumn{4}{|c|}{ as onset in the initial open syllable } \\
\hline (45) & $\begin{array}{l}/ \mathrm{m} \ominus \cdot \ln \cdot \mathrm{m} \sigma n / \\
/ \mathrm{m} \Lambda \cdot \mathrm{g} \Lambda \mathrm{p} /\end{array}$ & 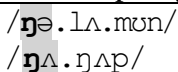 & $\begin{array}{c}\text { day-dream } \\
\text { open one's mouth }\end{array}$ \\
\hline
\end{tabular}

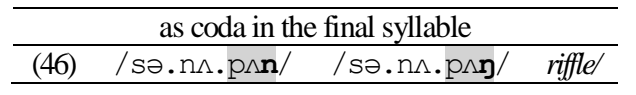

Nasals in Indonesian change into weaker nasals in Palembang Malay: bilabial $\rightarrow$ velar in (45); and alveolar $\rightarrow$ velar in (46).

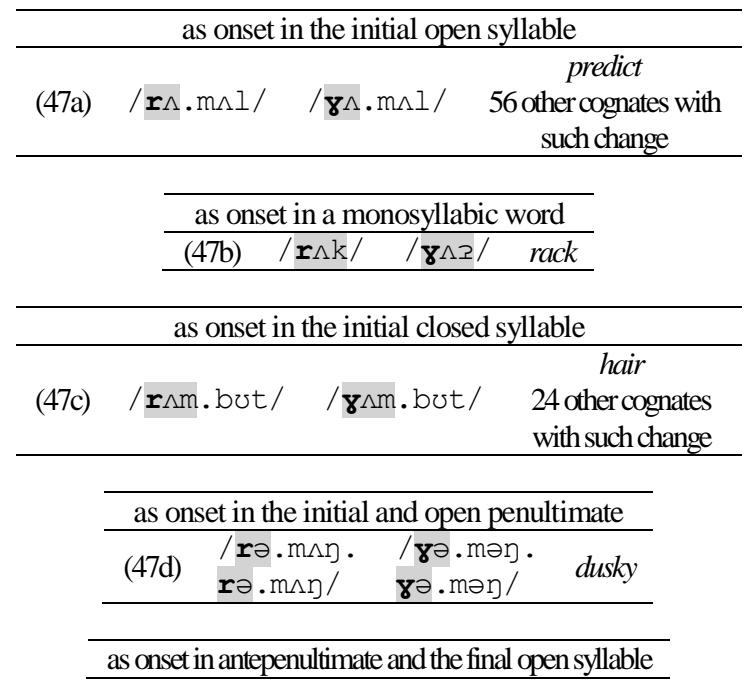

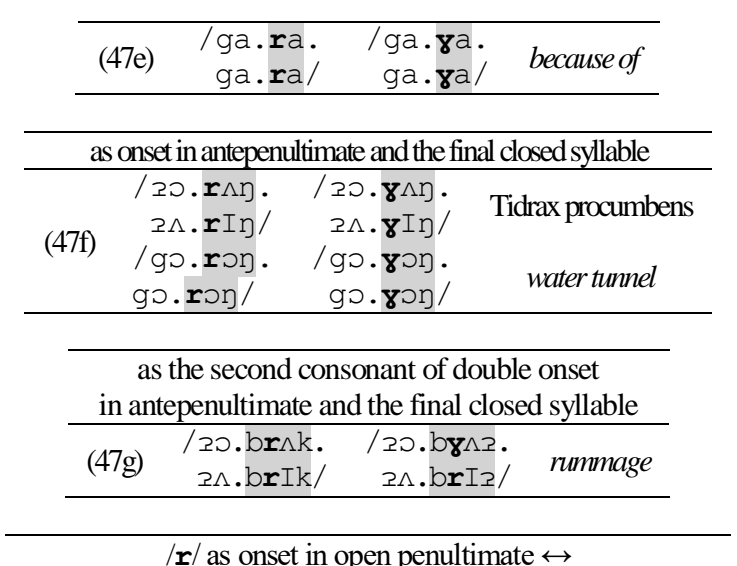

$/ \gamma /$ as the second consonant of double onset in the initial open syllable

(47h) /kə.ro.pos/ /kro.pos/ porous




\begin{tabular}{|c|c|c|}
\hline \multicolumn{3}{|c|}{$\begin{array}{l}\text { as the second consonant of double onset } \\
\text { in the initial open syllable }\end{array}$} \\
\hline$(471)$ & /sri.ka.ja/ /syi.ka.jo/ & $\begin{array}{c}\text { Annona } \\
\text { squamosa } \\
5 \text { other cognates } \\
\text { with such change }\end{array}$ \\
\hline \multicolumn{3}{|c|}{$\begin{array}{l}\text { as the second consonant of double onset in the initial closed } \\
\text { syllable }\end{array}$} \\
\hline \multirow[t]{3}{*}{$(47 \mathrm{j})$} & /prIn.sIp/ & principle \\
\hline & $\begin{array}{l}/ \mathbf{r} / \text { as onset in open pre-antepent } \\
\leftrightarrow / \mathrm{\gamma} / \text { as onset in open antepenu }\end{array}$ & $\begin{array}{l}\text { ultimate } \\
\text { ultimate }\end{array}$ \\
\hline & $\begin{array}{cc}\text { (p7k) } \begin{array}{c}\text { pr.ri. } \\
\text { ba.ha.sa/ }\end{array} & \text { ba.so } \\
\end{array}$ & ; proverb \\
\hline \multicolumn{3}{|c|}{ as onset in open penultimate } \\
\hline$(471)$ & /Cə.ru.tu/ & $\begin{array}{c}\text { cigar } \\
44 \text { other } \\
\text { cognates with } \\
\text { such change }\end{array}$ \\
\hline \multicolumn{3}{|c|}{ as onset in closed penultimate } \\
\hline$(47 \mathrm{~m})$ & /po.rsn.ti/ /po. $\mathbf{y} \wedge n \cdot t i /$ & $\begin{array}{c}\text { tool } \\
8 \text { other cognates } \\
\text { with such change }\end{array}$ \\
\hline
\end{tabular}

as the second consonant of double onset in the initial closed syllable and in the final closed syllable

(4/n) /pro.gr $\wedge \mathrm{m} /$ /p8. $98 \wedge \mathrm{m} /$ program

\begin{tabular}{|c|c|c|c|}
\hline \multicolumn{4}{|c|}{$\begin{array}{l}\text { as the second consonant of double onset in the initial closed } \\
\text { syllable and as coda in the final closed syllable }\end{array}$} \\
\hline$(47 \mathrm{o})$ & $\begin{array}{l}\text { /tro.to. } \\
\text { wAr/ }\end{array}$ & 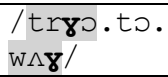 & sidewalk \\
\hline \multicolumn{4}{|c|}{ as onset in the final open syllable } \\
\hline
\end{tabular}

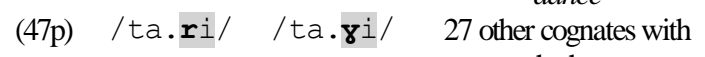
such change

$/ r /$ as the second consonant of double onset in the final open syllable $\leftrightarrow / \gamma /$ as onset in the final open syllable

\begin{tabular}{|c|c|c|c|}
\hline$(47 q)$ & /Jus.tru/ & /Jus.tə. & instead \\
\hline \multicolumn{4}{|c|}{ as onset in the final closed syllable } \\
\hline$(47 r)$ & rut/ & $\mathbf{\gamma} \mathbf{t / /}$ & \\
\hline
\end{tabular}

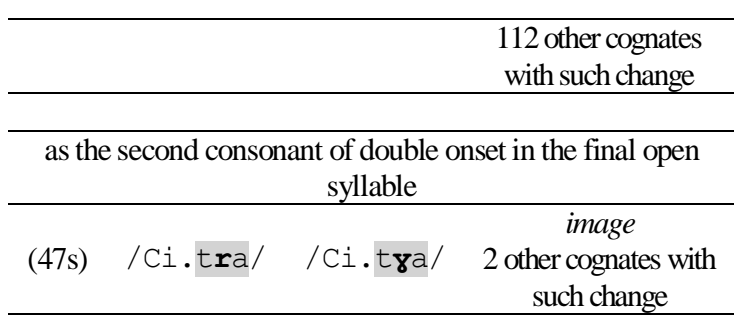

as the second consonant of double onset in the final closed syllable

\begin{tabular}{|c|c|c|c|}
\hline$(47 \mathrm{t})$ & $/ m v n \cdot \operatorname{Cr} \Lambda t /$ & /mun.C $8 \wedge t /$ & $\begin{array}{c}\text { spurt } \\
12 \text { other } \\
\text { cognates with } \\
\text { such change }\end{array}$ \\
\hline
\end{tabular}

$/ \mathbf{r} /$ as onset in the final closed syllable $\leftrightarrow$

$/ \mathrm{\gamma} /$ as the second consonant onset in the final closed syllable

\begin{tabular}{|c|c|c|c|c|}
\hline$(47 \mathrm{u})$ & /Cən.də.run/ & /Cən & lyon/ & tend \\
\hline & \multicolumn{3}{|c|}{ as coda in a monosyllabic word } & \\
\hline & $(47 \mathrm{v})$ /Cor/ & $/ \mathrm{Cog}$ & cast & \\
\hline \multicolumn{5}{|c|}{ as coda in the initial syllable } \\
\hline
\end{tabular}

(47w) /pər.b $\wedge \mathrm{n} / \mathrm{p}$ / $8 \cdot \mathrm{b} \wedge \mathrm{n} / 35$ other cognates with such change

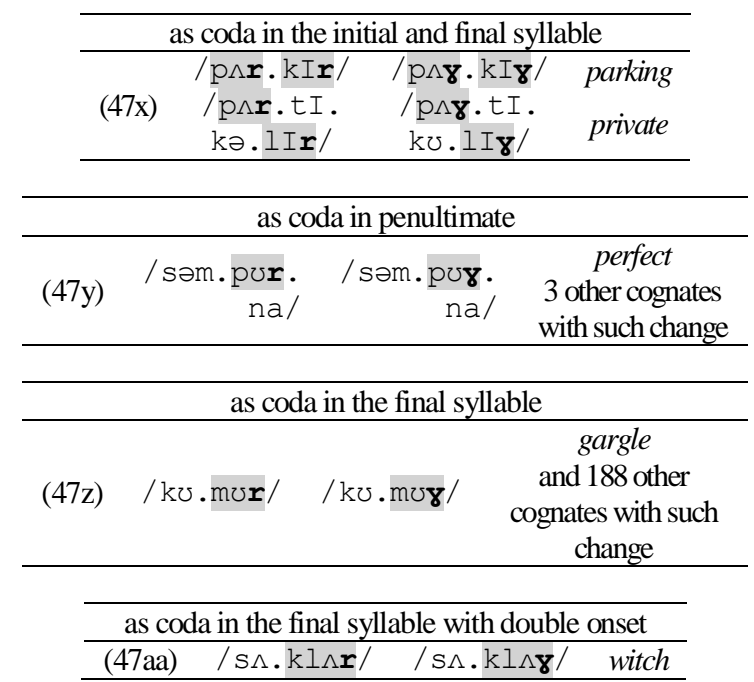

Thrill in Indonesian change into weaker thrill consonants in Palembang Malay: post-alveolar $\rightarrow$ uvular in (47a-aa).

\begin{tabular}{|c|c|c|}
\hline \multicolumn{3}{|c|}{ as onset in closed penultimate } \\
\hline$(48 a)$ & $\begin{array}{rr}\text { /sə.rIm. } & \text { /sə.1Im. } \\
\text { pət } / & \text { pət } /\end{array}$ & get entangled \\
\hline
\end{tabular}

\begin{tabular}{ll}
\hline \multicolumn{3}{c}{ as coda in the final syllable } \\
\hline (48b) /CI.bIr/ / $ə . \mathrm{bIl} /$ curl/mock \\
\hline
\end{tabular}

Thrill in Indonesian change into weaker segments, lateral, in Palembang Malay: post-alveolar $\rightarrow$ alveolar in (48a-b). 


\begin{tabular}{|c|c|c|c|}
\hline \multicolumn{4}{|c|}{ as onset in the initial open syllable } \\
\hline (50a) & /xI.jム.n^t/ & 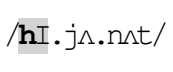 & $\begin{array}{l}\text { deceitl } \\
\text { betrayal }\end{array}$ \\
\hline \multicolumn{4}{|c|}{ as onset in the final closed syllable } \\
\hline $\begin{array}{l}(49) \\
(50 \mathrm{~b})\end{array}$ & 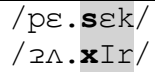 & $\begin{array}{l}/ p \varepsilon \cdot h \varepsilon ? / \\
/ \mathrm{s} \cdot \mathbf{h I \gamma /}\end{array}$ & $\begin{array}{c}\text { flat nose } \\
\text { end }\end{array}$ \\
\hline
\end{tabular}

\begin{tabular}{|c|c|c|c|}
\hline \multicolumn{4}{|c|}{ as coda in the initial syllable } \\
\hline$(50 c)$ & 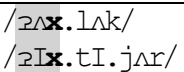 & 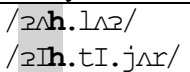 & effont \\
\hline
\end{tabular}

Fricatives in Indonesian change into weaker fricatives in Palembang: alveolar $\rightarrow$ glottal in (49); uvular $\rightarrow$ glottal in (50a-c)

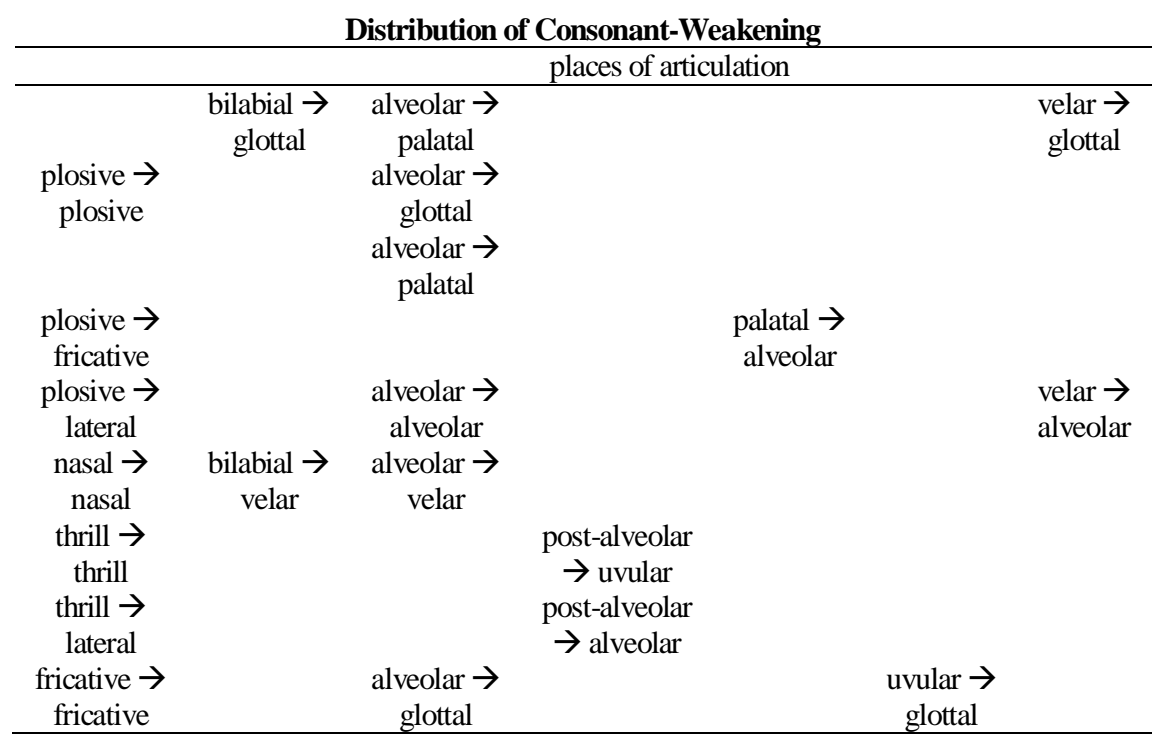

Plosives are mostly weakened into glottal plosive $/ \mathrm{s} / \mathrm{:} / \mathrm{p} / \mathrm{p} / \mathrm{s} / \mathrm{in}(37 \mathrm{a}), / \mathrm{t} / \mathrm{p} / \mathrm{s} /$ in $(39 \mathrm{a}-\mathrm{b}), / \mathrm{k} / \rightarrow / \mathrm{s} /$ in $(41 \mathrm{a}-\mathrm{i})$; even, the latest mentioned weaking involves myriads of cognates, i.e., 206 of cognates becoming the corpus. Based on syllabic structures, the glottal plosive is also distributed to occur in various environment: as onset in the initial open syllable in (39a), as onset in the final closed syllable in (41a), as coda in a monosyllabic word in (41 b), as coda in the initial syllable in (41 c), as coda in penultimate in (4d), as coda in antepenultimate and the final syllable in (41e), as coda in antepenultimate and the final syllable with double onset in (41f), as coda in the final syllable in (41g-h), and as coda in the final syllable with double onset in (41i). Two fricatives, $/ \mathrm{s} /$ and $/ \mathrm{x} /$, are also weakened in into glottal fricative $/ \mathrm{h} /: \mathrm{s} / \rightarrow / \mathrm{h} /$ in (49) and $/ \mathrm{x} / \rightarrow / \mathrm{h} /$ in $(50 \mathrm{a}-\mathrm{c})$. The glottal fricative occurs as onset in the open initial syllable in (50a), as onset in the closed final syllable in (49) and (50b), and as coda in the final syllable in $(50 \mathrm{c})$.

Consonant-change into glottal (either plosive glottal or fricative glottal can also be described as a phenomenon of glottalization. Therefore, besides described as consonant weakening, phenomena described in the previous paragraph can also be described as glottalization. Furthermore, phenomena of $/ \mathrm{s} / \rightarrow / \mathrm{s} /$ in $(12), / \mathrm{h} / \rightarrow / \mathrm{s} /$ in $(17 \mathrm{a}-\mathrm{b}), / \mathrm{w} / \rightarrow$ $/ \mathrm{s} /$ in $(18 \mathrm{a}-\mathrm{b}), / \mathrm{g} / \rightarrow / \mathrm{s} /$ in $(28 \mathrm{a}-\mathrm{b}), / \mathrm{m} / \rightarrow / \mathrm{s} /$ in $(29 \mathrm{a}-\mathrm{b}), / \mathrm{n} / \rightarrow / \mathrm{s} /$ in $(31), / \mathrm{g} / \rightarrow / \mathrm{s} /$ in (32), $/ r / \rightarrow / 2 /$ in (35), and $/ 1 / \rightarrow / 2 /$ in (36) can also be described a glottalization.

Consequently, there are two types of glottalization: (1) glottalization in consonant strengthening, examples of which are summarized in the previous paragraph and (2) glottalization in consonant weakening, examples of which are summarized in the paragraph before the previous one. Glottalization in consonant strengthening involve plosives, nasals, thrills fricatives, lateral and approximant. Meanwhile, glottalization in consonant weakening only involve plosives and fricatives. 
Glottalization is also reported to found, by Jaya (2018, p.51), in the phonological interference of Buginese into Indonesian. Glottalization in consonant strengthening involves $/ \mathrm{b} / \rightarrow / \mathrm{s} / \mathrm{d} / \mathrm{d} / \rightarrow / \mathrm{s} /$, and $/ \mathrm{h} / \rightarrow / \mathrm{s} /$; while glottalization in consonant weakening involves $/ \mathrm{p} / \rightarrow / \mathrm{s} / \mathrm{t} / \mathrm{t} \rightarrow \mathrm{s} / \mathrm{h}$, and $/ \mathrm{k} / \rightarrow / \mathrm{s} /$. Jaya also reported that all of consonants involved in the glottalization occur as coda either in the final syllable or in the monosyllabic word.

As already mentioned before, $/ \mathrm{k} / \rightarrow / \mathrm{s} /$ found in 206 cognates becoming the corpus. In other words, such consonant weakening is productive in Palembang Malay. Another productive one is $/ r / \rightarrow / \gamma /$ as can be seen in (47a-aa) as this such consonant weakening involves 430 of cognates becoming the corpus. The consonants involved in this such consonant weaking occurs both as onset and coda in various environment of syllabic structures as can be seen in (47a-aa).

\section{Lenition}

Lenition belongs to consonant weakening as Bybee and Easterday (2019, p. 267) highlighted that lenition is the weakening of a consonant. However, different from the previous section which ignores whether the consonants weakened are either fortis or lenis, this section describes the phenomena of certain fortis consonants in Indonesian change into lenis consonants in Palembang Malay; such phenomenon is popularly known as lenition.

\begin{tabular}{ccc}
\hline \multicolumn{3}{c}{ as onset in the final closed syllable } \\
\hline (51) $/ \mathrm{b} \Lambda \cdot \mathrm{p} \wedge$ ? $/ \mathrm{s} \wedge \cdot \mathrm{b} \wedge \mathrm{z} /$ father \\
\hline
\end{tabular}

A fortis plosive in Indonesian changes into a lenis plosive in Palembang Malay: bilabial $\rightarrow$ bilabial in (51).

\begin{tabular}{l}
\hline \multicolumn{3}{c}{ as onset in the initial open syllable } \\
\hline (53) $/ \mathbf{2} \wedge . \mathrm{s} \operatorname{In} / \mathrm{m} \wedge . \mathrm{s} \operatorname{In} / \quad$ salty \\
\hline
\end{tabular}

\begin{tabular}{ccc}
\hline \multicolumn{3}{c}{ as onset in the initial closed syllable } \\
\hline (52) $/ \mathrm{p} \wedge \mathrm{s}$. ti/ /m $\wedge$ s.ti/ sure/certain \\
\hline
\end{tabular}

Fortis plosives in Indonesian change into nasals (lenis segments) in Palembang Malay: bilabial $\rightarrow$ bilabial in (52); and glottal $\rightarrow$ bilabial in (53).

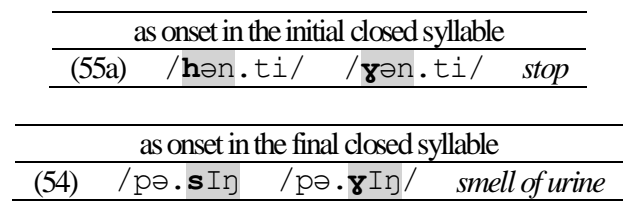

\begin{tabular}{c}
\hline as coda in the final syllable \\
\hline$(55 \mathrm{~b}) / \mathrm{p} \cdot \mathrm{\eta} \wedge \mathrm{h} / \mathrm{p} \cdot \mathrm{p} \wedge \mathrm{\gamma} /$ conceited \\
\hline
\end{tabular}

Fortis fricatives in Indonesian change into thrills (lenis segments) in Palembang: alveolar $\rightarrow$ uvular in (54); and glottal $\rightarrow$ uvular in (55a-b).Lenition Distribution

\begin{tabular}{|c|c|c|c|}
\hline & \multicolumn{3}{|c|}{ places of articulation } \\
\hline $\begin{array}{l}\text { plosives } \rightarrow \text { plosives } \\
\text { plosives } \rightarrow \text { nasals } \\
\text { fricatives } \rightarrow \text { thrills }\end{array}$ & $\begin{array}{l}\text { bilabial } \rightarrow \text { bilabial } \\
\text { bilabial } \rightarrow \text { bilabial }\end{array}$ & alveolar $\rightarrow$ uvular & $\begin{array}{l}\text { glottal } \rightarrow \text { bilabial } \\
\text { glottal } \rightarrow \text { uvular }\end{array}$ \\
\hline
\end{tabular}

The distribution above shows that lenition is not as productive as fortition. Lenition only involves plosive $\rightarrow$ plosive, plosives $\rightarrow$ nasals, and fricatives $\rightarrow$ thrills. Different from certain productive phenomena which involve myriads of cognates (as mentioned in the previous section), every phenomenon of lenition only involves a single cognate. However, the consonants involved in lenition are distributed quite variously: as onset in the initial open syllable in (53), as onset in the closed final syllable in (52) and (55a), as onset in the final closed syllable in (51) and (54), and as coda in (55b). 


\section{CLOSING}

The distribution of consonants in Palembang Malay is different from the one in Indonesian and/or Malay as described in the earlier section. It is due to the fact that some consonants, i.e., / $/ \mathrm{q} / \mathrm{V} / \mathrm{,} / \Theta /$, and $/ \partial /$ are not found in the cognates becoming the corpus, either in the identical ones or the ones with sound changes. Those consonants may occur in other dialects of Malay.

Certain consonants occurring in Indonesian, i.e., $/ \mathrm{r} / \mathrm{f} / \mathrm{f} / \mathrm{f} / \mathrm{J} /$, and $/ \mathrm{x} /$, do not occur in Palembang Malay. Each of the consonant changes into another single-segmental of consonant in Palembang Malay. Even though they can occur in other Palembang Malay words, each of the following consonant changes into another segmental of consonant in certain

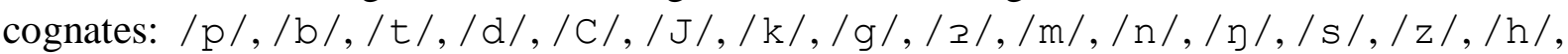
$/ \mathrm{l} /$, and $/ \mathrm{w} /$. Only one single-segmental consonant, i.e., $/ \mathrm{n} /$, and one single-segmental approximant, i.e., $/ \mathrm{j} /$, remains not to change in cognates becoming the corpus.

Consonant strengthening involves 101 cognates. Fortition involves 31 cognates. Consonants weakening involves 769 cognates. Lenition involves 6 cognates. Therefore, compared to Indonesian, weaker/lenis consonants tend to occur more in Palembang-Malay words.

Descriptions of phenomena of sound changes involving more than just single consonants, i.e., epenthesis, epithesis, consonant fusion, and consonant-cluster reduction, need to be carried out in order the hypothesis "weaker/lenis consonants occur more in Palembang-Malay words" can be more accepted. Descriptions of sound changes involving other segmental sounds, i.e., vowels and diphthongs, also need to be carried out. Therefore, the hypothesis "Palembang Malay, typologically, is weaker than Indonesian" can be accepted.

\section{BIBLIOGHRAPY}

Ayu Fauziyah \& Indrya Mulyaningsih. (2016). Perubahan bunyi pada tuturan resmi yang digunakan mahasiswa IAIN Syeikh Nurjati Cirebon. In Journal Indonesian Language Education and Literature, 2(1), 50-59. https://doi.org/10.24235/ileal.v2i1.1027

Balai Bahasa Sumatera Selatan. (2019). Kamus Palembang - Indonesia. Third Edition. Palembang: Balai Bahasa Sumatera Selatan.

Bybee, J. \& Easterday, S. (2019). Consonant strengthening: A crosslinguistic survey and articulatory proposal. In Linguistic Typology, 23(2) pp. 263-302. https://doi.org/10.1515/lingty-2019-0015

Crystal, D. (2008). A dictionary of linguistics and phonetics. Malden: Blackwell Publishing. https://doi.org/10.1002/9781444302776

Fauzi Syamsuar (2012). Realisasi struktur silabel di akhir kata asing/pinjaman oleh penutur jati bahasa Sunda. In Yasir N. and Yanti. Editor. Konferensi linguistik Tahunan Atma Jaya Kesepuluh, pp. 57-61. Jakarta: Pusat Kajian bahasa dan Budaya Universitas Katolik Atma Jaya.

Fauzi Syamsuar (2015). Penyelarasan Fonologis dalam Satuan Leksikal Indonesia Yang Disalin dari Bahasa Inggris. Disertasi. Faculty of Humanities Universitas Indonesia.

Fauzi Syamsuar (2018). Aspek Fonologis dalam Pembentukan Kata. Bogor: UIKA Press.

Fromkin, V., Rodman, R., \& Hyams, N. (2014). An introduction to language. Tenth Edition. Boston: Wadworth, Cencage Learning.

Harimurti Kridalaksana (2008) Kamus Linguistik. Fourth Edition. Jakarta: Gramedia Pustaka Utama.

Hasan Alwi. (2013). Perbandingan tatabahasa Dewan dengan tatabahasa baku bahasa Indonesia. Kuala Lumpur: Dewan Bahasa dan Pustaka.

Jaya. (2018). Phonological interference of Buginese into Indonesian by Buginese speakers in Tolitoli Central Sulawesi. Thesis. Faculty of Humanities Universitas Diponegoro Semarang.

Matthews, P. (1997). The concise Oxford dictionary of linguistics. Oxford: Oxford University Press.

SIL International, Indonesian Branch. (2006). Languages of Indonesia. Jakarta: SIL International, Indonesia Branch.

Trask, R. L. (1996). A Dictionary of Phonetics and Phonology. London: Routledge. 
Fauzi Syamsuar

\section{APPENDIX:}

A list of cognates becoming the corpus which can be accessed through: https://www.youtu.be/nmi_jMnuzJQ. 